\title{
Effects of copepod size on fish growth: a model based on data for North Sea sandeel
}

\author{
Mikael van Deurs ${ }^{1,3, *}$, Christian Jørgensen ${ }^{2}$, Øyvind Fiksen ${ }^{2}$ \\ ${ }^{1}$ DTU Aqua National Institute of Aquatic Resources, Technical University of Denmark (DTU), Jægersborg Alle 1, \\ Charlottenlund Castle, 2920 Charlottenlund, Denmark \\ ${ }^{2}$ Thormøhlensgate 53B 3rd floor, Department of Biology, University of Bergen, PO Box 7803, 5020 Bergen, Norway \\ ${ }^{3}$ Present address: Lund University, Sölvegatan 37, International Postal Code 50, Lund, Sweden
}

\begin{abstract}
In productive marine off-shore ecosystems, the flow of energy from zooplankton to large predators is channeled through a few species of short-lived, highly abundant schooling planktivorous fish. There are indications that these species respond to qualitative and phenological changes in the zooplankton. If so, the climate-induced alterations of the local copepod communities that we see in temperate and arctic regions may influence the energy flux in marine food chains. In order to investigate how different processes contribute to the relationship between copepod size and fish growth, we merged 2 mechanistic models from relevant data: (1) a model of the bioenergetics and stomach filling/evacuation dynamics, and (2) a Holling type II functional response model that encompasses visual range from basic principles. The model predicts that going from a situation where large Calanus copepods $(2 \mathrm{~mm})$ dominate the prey field of lesser sandeel Ammodytes marinus in the central North Sea to a situation where only relatively small $(1 \mathrm{~mm})$ and less energy-rich copepods are available roughly halves the energy intake of sandeels even if prey biomass concentration remains constant. Visual constraint on foraging was the most important factor, followed by handling time limitation and prey energy content. These limitations became stronger with increasing fish length, showing that copepod size and energy content have a strong effect on the specific growth potential of these fish.
\end{abstract}

KEY WORDS: Prey preference - Bioenergetics - Optimal foraging - North Sea regime-shift · Climate change $\cdot$ Ammodytes $\cdot$ Holling disc $\cdot$ Calanus $\cdot$ Handling time limitation $\cdot$ Food quality

\section{INTRODUCTION}

In marine productive off-shore ecosystems, the flow of energy from zooplankton to large predators (fish, birds, and mammals) is often channeled through a few species of short-lived, highly abundant schooling planktivorous fish (also known as the small pelagics, forage fish, or short-lived industrial species). While it is beyond doubt that many of these massive populations have varied radically in stock size on decadal time scales (see Checkley et al. 2009), the underlying environmental processes are still only vaguely understood. Variance in total zooplankton abundance does not seem to tell the whole story, and some more de-

${ }^{*}$ Corresponding author: mvd@aqua.dtu.dk tailed hypotheses therefore involve the occurrence of qualitative and phenological changes in the food source (Beaugrand et al. 2003, Möllmann et al. 2003, van der Lingen et al. 2006). Climate-induced alterations of the local copepod communities have been reported in both temperate and Arctic regions (Planque \& Taylor 1998, Möllmann et al. 2003, Beaugrand 2004, Helaouët \& Beaugrand 2009, Coyle et al. 2011, Kjellerup et al. 2012).

While most zooplankton in the North Sea reaches sizes up to $1.3 \mathrm{~mm}$ (prosome length), Calanus finmarchicus and C. helgolandicus are the only abundant copepods that become bigger (adults reach lengths of 2 to $3 \mathrm{~mm}$; Pitois et al. 2009). The seasonal Attribution Licence. Use, distribution and reproduction are unrestricted. Authors and original publication must be credited. 
timing and distribution differ between the 2 species. C. finmarchicus resides to the north and peaks in the spring when adults are advected into the North Sea from overwintering areas in the Atlantic. In contrast, C. helgolandicus resides in the south and is most abundant in late summer and fall, when the water in the North Sea has warmed up. In recent times, the abundance of $C$. finmarchicus has declined all over the northeastern Atlantic, whereas C. helgolandicus has increased, but only in the southern North Sea (Planque \& Taylor 1998). The decline in C. finmarchicus has been linked to reduced survival of fish larvae (Beaugrand et al. 2003, van Deurs et al. 2009) and food consumption and growth of lesser sandeel in the North Sea (van Deurs et al. 2014). The northward shift in the distribution of $C$. finmarchicus may have caused a northward shift in the feeding migration of North Sea herring (Corten 2000). In comparison, little attention has been dedicated to the long-term changes in abundance and biomass of smaller calanoids such as the genera Temora, Pseudocalanus, Centropages, Paracalanus, Oithona, Microsetella, and Oncaea, (Nielsen et al. 1993), but the combined biomass of all calanoid species has seemingly remained unchanged in the northeastern Atlantic (including the North Sea) (Planque \& Batten 2000, Beaugrand 2004).

Lesser sandeel Ammodytes marinus feed primarily on copepods and mainly during spring (Macer 1966, Winslade 1974, MacLeod et al. 2007). They are highly abundant in the Dogger area (central North Sea) at the southerly distribution limit of the large $C$. finmarchicus. This suggests a particular susceptibility to fluctuations in the spring invasion of $C$. finmarchicus, if we expect changes to be most dramatic along the distribution margins (Hampe \& Petit 2005). Field observations have indicated higher food consumption by sandeels feeding on large Calanus copepods, and the length-at-age of lesser sandeels began decreasing in the late 1980s, simultaneously with the $C$. finmarchicus decline (van Deurs et al. 2014). The question remaining to be answered is why sandeels cannot uphold high consumption and growth rates when only small copepods are available. One possible answer is that the overall biomass of copepods is reduced when large $C$. finmarchicus are removed, leaving less food for pelagic zooplanktivorous fish. However, an alternative hypothesis is that small zooplankton is a 'poor' food resource for fish (Brooks \& Dodson 1965). In order to address this hypothesis from a theoretical point of view, we assembled a mechanistic model parameterized for lesser sandeels in the Dogger area. We expected that reduction in size of copepods would lead to (1) reduced encounter rates due to reduced detection distance (Aksnes \& Utne 1997); (2) potential handling time limitation, since every time the fish needs to slow down to capture, engulf, and handle a single prey item, less time is left for searching (Jeschke et al. 2002); and (3) reduced food quality, since small non-diapausing copepods ( $<1$ yr life span) do not accumulate lipid reserves and are therefore less rich in energy (i.e. Schnack-Schiel \& Hagen 1994).

\section{MATERIALS AND METHODS}

In order to investigate how different processes contribute to the relationship between copepod size and fish growth, we merged 2 mechanistic models: (1) a bioenergetics model that describes metabolic budgets, stomach filling, and evacuation dynamics (van Deurs et al. 2010, 2014, van Deurs et al. 2011); and (2) a Holling type II functional response model that encompasses visual range from basic principles of prey size, light attenuation, and optical properties of sea water (Huse \& Fiksen 2010, Varpe \& Fiksen 2010). The discrete universal processes in the model include light irradiance, light attenuation, prey detection distance, clearance rate, prey encounter rate, stomach filling dynamics, stomach evacuation dynamics, energy assimilation, and metabolism. The final output of the full model is an estimate of the specific net energy intake (i.e. energy available for structural growth, growth of reproductive organs, or energy reserves) accumulated over a desired period of time $\left(\varepsilon, \mathrm{J} \mathrm{g}^{-1}\right.$ fish period $\left.{ }^{-1}\right)$. For the present use, the desired time period is the foraging period in spring and the model is formulated as a function of 6 variables, fish length $(L, \mathrm{~cm})$, copepod prosome length $(l, \mathrm{~mm})$, prey energy density $\left(\partial, \mathrm{J} \mathrm{g}^{-1}\right.$ wet weight $[\mathrm{ww}])$, handling time $\left(H, \mathrm{~s}\right.$ ind.$\left.^{-1}\right)$, prey concentration $\left(P\right.$, copepods $\left.\mathrm{m}^{-3}\right)$, chlorophyll a ( $\mathrm{chl}$ a) concentration $\left(\mathrm{chl} a, \mathrm{mg} \mathrm{m}^{-3}\right)$ :

$$
\varepsilon(L, l, \partial, H, P, \operatorname{chl} a)=\frac{\sum_{t=1}^{T}[U(t)-M(t)]}{W}
$$

where $W$ is fish weight $(g, w w), U$ is surplus energy uptake gained from feeding $\left(\mathrm{J} \mathrm{h}^{-1}\right)$, and $M$ is the metabolic cost $\left(\mathrm{J} \mathrm{h}^{-1}\right)$, excluding the cost of digesting food, which is accounted for by the assimilation efficiency coefficient in Eq. (2) in Table 1. The model is resolved into $T$ hourly time steps, where $U-M$ is summed. All equations leading to $U, M$, and $W$ are summarized in Table 1. The model was parameterized for lesser sandeels in the central North Sea (Dogger, $55^{\circ} \mathrm{N}, 2^{\circ} \mathrm{E}$ ) feeding from 1 April to 1 June 
Table 1. Model overview. All calculations were made for a depth of $30 \mathrm{~m}$ representing roughly the depth of the chlorophyll and Calanus finmarchicus maximum on the western slopes of the Dogger Bank (Jónasdóttir \& Koski 2011). Unless mentioned otherwise, default handling time in the model was $2 \mathrm{~s}$, default chlorophyll a concentration was $2 \mathrm{mg} \mathrm{m}^{-3}$ (a realistic value for this region, taken from Radach \& Pätsch 1997), and default prey concentration was $0.06 \mathrm{~g} \mathrm{~m}^{-3}$ (wet mass). (Table 1 cont. on next page)

\begin{tabular}{|c|c|c|c|}
\hline Eq. & Explanation and units & Equation & Description of parameters \\
\hline (1) & $\begin{array}{l}\text { Metabolism } \\
\left(M_{i} \mathrm{~J} \mathrm{~h}^{-1}\right)\end{array}$ & $M_{\mathrm{d}, \mathrm{h}}=\alpha \mathrm{SMR}_{\mathrm{d}, \mathrm{h}}$ & $\begin{array}{l}\alpha=\text { activity multiplier }=1.5 \text { (assuming that fish } \\
\text { are foraging } 12 \mathrm{~h} \mathrm{~d}^{-1} \text { and spend } 2 \text { times } \\
\text { standard metabolic rate (SMR) during active } \\
\text { periods, digestive processes excluded) (simpli- } \\
\text { fied from van Deurs et al. } 2010 \text { ). SMR }\left(\mathrm{J} \mathrm{h}^{-1}\right) \text { is } \\
\text { modeled in Eq. (3). } \mathrm{d} \text { and } \mathrm{h} \text { refer to a given } \\
\text { day and hour of the day in the simulation runs }\end{array}$ \\
\hline$(2)$ & $\begin{array}{l}\text { Surplus energy uptake } \\
\left(U_{i} \mathrm{~J} \mathrm{~h}^{-1}\right)\end{array}$ & $U_{\mathrm{d}, \mathrm{h}}=\left\{\begin{array}{l}\text { if }\left(S_{\max }-S_{\mathrm{d}, \mathrm{h}} \leq 0\right) \rightarrow \varphi\left[i_{\mathrm{d}, \mathrm{h}}-\left(S_{\mathrm{d}, \mathrm{h}}-S_{\max }\right)\right]\end{array}\right.$ & $\begin{array}{l}S=\text { stomach fullness (see Eq. 5); } \varphi=\text { assimilation } \\
\text { efficiency }=0.7 \text { (Ciannelli et al. 1998); } S_{\max }= \\
\text { maximum gut capacity (J) }=4 \% \text { of fish weight } \\
\text { times energy density of prey (derived from van } \\
\text { Deurs et al. 2010) (fish weight as a function of } \\
\text { fish length is modeled in Eq. } 4 \text { ) } ; i=\text { encounter } \\
\text { rate (see Eq. } 7 \text { ) }\end{array}$ \\
\hline (3) & $\begin{array}{l}\text { Standard metabolic rate } \\
\left(\mathrm{SMR}_{i} \mathrm{~J} \mathrm{~h}^{-1}\right)\end{array}$ & $\begin{array}{l}\mathrm{SMR}_{\mathrm{d}, \mathrm{h}}=1.37 \times W^{0.8} \times\left(0.08 \tau_{\mathrm{d}}-0.25\right) \\
\text { van Deurs et al. }(2011)\end{array}$ & $\begin{array}{l}W=\text { fish weight (g wet weight), modeled as a } \\
\text { function of fish length in Eq. }(4) ; \tau_{\mathrm{d}}=\text { ambient } \\
\text { temperature on a given day (van Deurs et al. } \\
2010 \text { ) }\end{array}$ \\
\hline$(4)$ & Fish weight $\left(W_{i} g\right)$ & $\begin{array}{l}W=0.0028 L^{3.06} \\
\text { van Deurs et al. (2013) }\end{array}$ & $\begin{array}{l}L=\text { fish length }(\mathrm{cm}), \text { which was varied from } 5 \text { to } \\
17 \mathrm{~cm} \text { in the model }\end{array}$ \\
\hline (5) & Stomach fullness $(S ; \mathrm{J})$ & $S_{\mathrm{d}, \mathrm{h}}=S_{\mathrm{d}, \mathrm{h}-1}-\mu S_{\mathrm{d}, \mathrm{h}-1}+i_{\mathrm{d}, \mathrm{h}-1}$ & $\begin{array}{l}\mu=\text { stomach evacuation coefficient (see Eq. 6); } \\
i=\text { encounter rate (see Eq. } 7 \text { ) }\end{array}$ \\
\hline (6) & $\begin{array}{l}\text { Stomach evacuation } \\
\text { coefficient (or digestion } \\
\text { rate) }(\mu)\end{array}$ & $\begin{array}{l}\mu=0.035 \mathrm{e}^{0.054 \tau_{\mathrm{d}}} \frac{\partial}{\partial} \\
\text { The exponential model and parameterization } \\
\text { were adopted from van Deurs et al. (2013); the } \\
\text { term } \partial^{*} / \partial \text { was added to take into account that } \\
\text { digestion rate is inversely proportional to the } \\
\text { energy density of the prey (Andersen } 1999 \text {, } \\
\text { Temming \& Herrmann 2001) }\end{array}$ & $\begin{array}{l}\tau_{\mathrm{d}}=\text { ambient temperature on a given day (van } \\
\text { Deurs et al. 2010); } \partial=\text { energy density of prey }(\mathrm{J} \\
\mathrm{g}^{-1} \text { wet weight) }=5600 \text { for large copepods and } \\
3200 \text { for small copepods (see van Deurs et al. } \\
2013 \text { for the chosen energy densities); } \partial^{*}= \\
\text { energy density of the experimental prey }\left(\mathrm{J} \mathrm{g}^{-1}\right. \\
\text { wet weight) }=4400 \text { (Verkuil et al. 2003) }\end{array}$ \\
\hline \multirow[t]{2}{*}{ (7) } & Encounter rate $\left(i_{i} \mathrm{~J}\right)$ & $i_{\mathrm{d}, \mathrm{h}}=\left(\frac{\beta_{\mathrm{d}, \mathrm{h}}(P / w)}{1+H \beta_{\mathrm{d}, \mathrm{h}}(P / w)}\right) w \partial$ & \\
\hline & & $\begin{array}{l}\text { The expression in parentheses was adapted from } \\
\text { Varpe \& Fiksen (2010) }\end{array}$ & $\begin{array}{l}\left.\beta=\text { search rate }\left(\mathrm{m}^{3} \mathrm{~s}^{-1}\right) \text { (see Eq. } 8\right) ; P=\text { prey } \\
\text { biomass concentration ( } \mathrm{g} \mathrm{m}^{-3} \text {, wet mass); } W= \\
\text { weight of prey copepod ( } \mathrm{g} \text { wet weight) } \\
\text { (modeled as a function of prosome length in } \\
\left.\text { Eq. } 11) ; H=\text { handling time ( } \mathrm{s} \text { ind }{ }^{-1}\right), \text { which was } \\
\text { varied in the sensitivity analysis from } 1 \text { to } 10 ; \partial= \\
\text { energy density of prey }\left(\mathrm{J} \mathrm{g}^{-1} \text { wet weight) }\right.\end{array}$ \\
\hline (8) & $\begin{array}{l}\text { Search rate or } \\
\text { clearance rate }\left(\beta ; \mathrm{m}^{3} \mathrm{~s}^{-1}\right)\end{array}$ & $\begin{array}{l}\beta_{\mathrm{d}, \mathrm{h}}=1 / 2 \pi R_{\mathrm{d}, \mathrm{h}}^{2} V \\
\text { Varpe \& Fiken (2010) }\end{array}$ & $\begin{array}{l}R=\text { prey detection distance (see Eq. } 9) ; V= \\
\text { swimming velocity of fish (body lengths } \mathrm{s}^{-1} \text { ) }= \\
1.5 \text { (van Deurs et al. 2010) }\end{array}$ \\
\hline (9) & $\begin{array}{l}\text { Prey detection } \\
\text { distance }(\mathrm{m})\end{array}$ & $\begin{array}{l}R_{\mathrm{d}, \mathrm{h}}^{2} \mathrm{e}^{c R}=\frac{C A E I_{\mathrm{d}, \mathrm{h}}}{k+I_{\mathrm{d}, \mathrm{h}}} \\
\text { Aksnes \& Utne (1997) }\end{array}$ & $\begin{array}{l}\text { Equation was solved by means of Newton- } \\
\text { Raphson iteration and derivation (Aksnes \& } \\
\text { Utne } 1997) ; C=\text { beam attenuation coefficient } \\
\text { (see Eq. } 12) ; C \text { is the contrast }=0.3 \text { (Varpe } \& \\
\text { Fiksen } 2010) ; A \text { is image area }\left(\mathrm{m}^{2} \text { ) of copepods }\right. \\
\text { (calculated as an ellipse with length } l \text { and width } \\
1 / 2) ; I \text { is ambient irradiance (see Eq. } 10) ; E= \\
\text { visual capacity; } k \text { is a composite saturation } \\
\text { parameter; } E \text { and } k \text { are scaled such that } R \text { is ca. } \\
1 \text { body length when light is not limiting and } \\
\text { prey is } 1.5 \mathrm{~mm} \text { copepods (Varpe \& Fiksen } 2010 \text { ) }\end{array}$ \\
\hline$(10)$ & $\begin{array}{l}\text { Ambient irradiance } \\
\text { at } 30 \mathrm{~m} \text { depth }\end{array}$ & $\begin{array}{l}I_{\mathrm{d}, \mathrm{h}}=I_{0 \mathrm{~d}, \mathrm{~h}} \mathrm{e}^{-30 a} \\
\text { Varpe \& Fiksen (2010) }\end{array}$ & $\begin{array}{l}I_{0}=\text { average surface irradiance at latitude } 55^{\circ} \mathrm{N}_{i} \\
a=\text { diffusive attenuation (see Eq. } 13 \text { ). }\end{array}$ \\
\hline
\end{tabular}


Table 1 (continued)

\begin{tabular}{|c|c|c|c|}
\hline Eq. & Explanation and units & Equation & Description of parameters \\
\hline \multirow[t]{2}{*}{$(11)$} & \multirow[t]{2}{*}{$\begin{array}{l}\text { Wet weight of } \\
\text { copepods }(w ; g)\end{array}$} & $W=5\left(\frac{10^{3.13 \log (10001)-8.18}}{10^{6}}\right)$ & \multirow[t]{2}{*}{$l=$ prey length (length of prosome; mm) } \\
\hline & & $\begin{array}{l}\text { Adapted from Uye (1982). For the dry weight to } \\
\text { wet weight conversion, we applied a ratio of } 5 \\
\text { from Yamaguchi \& Ikeda (2000) }\end{array}$ & \\
\hline (12) & $\begin{array}{l}\text { Beam attenuation } \\
\left(C ; \mathrm{m}^{-1}\right)\end{array}$ & $\begin{array}{l}C=0.066+0.39 \mathrm{chl} a^{0.57} 0.93 \\
\text { Mobley }(1994)\end{array}$ & $\begin{array}{l}\text { chl } a=\mathrm{chl} a \text { concentration }\left(\mathrm{mg} \mathrm{m}^{-3}\right) \text {, which was } \\
\text { varied in the sensitivity analysis from } 1 \text { to } 5 \text { (as } \\
\text { suggested by Radach \& Pätsch 1997) }\end{array}$ \\
\hline (13) & $\begin{array}{l}\text { Diffusive attenuation } \\
\left(a_{;} \mathrm{m}^{-1}\right)\end{array}$ & $\begin{array}{l}a=0.125+\operatorname{chl} a\left(0.0506 \mathrm{e}^{-0.606 \mathrm{chl} a}+0.0285\right) \\
\text { Mobley }(1994)\end{array}$ & $\begin{array}{l}\text { chl } a=\mathrm{chl} a \text { concentration }\left(\mathrm{mg} \mathrm{m}^{-3}\right) \text {, which was } \\
\text { varied in the sensitivity analysis from } 1 \text { to } 5 \text { (as } \\
\text { suggested by Radach \& Pätsch } 1997 \text { ) }\end{array}$ \\
\hline
\end{tabular}
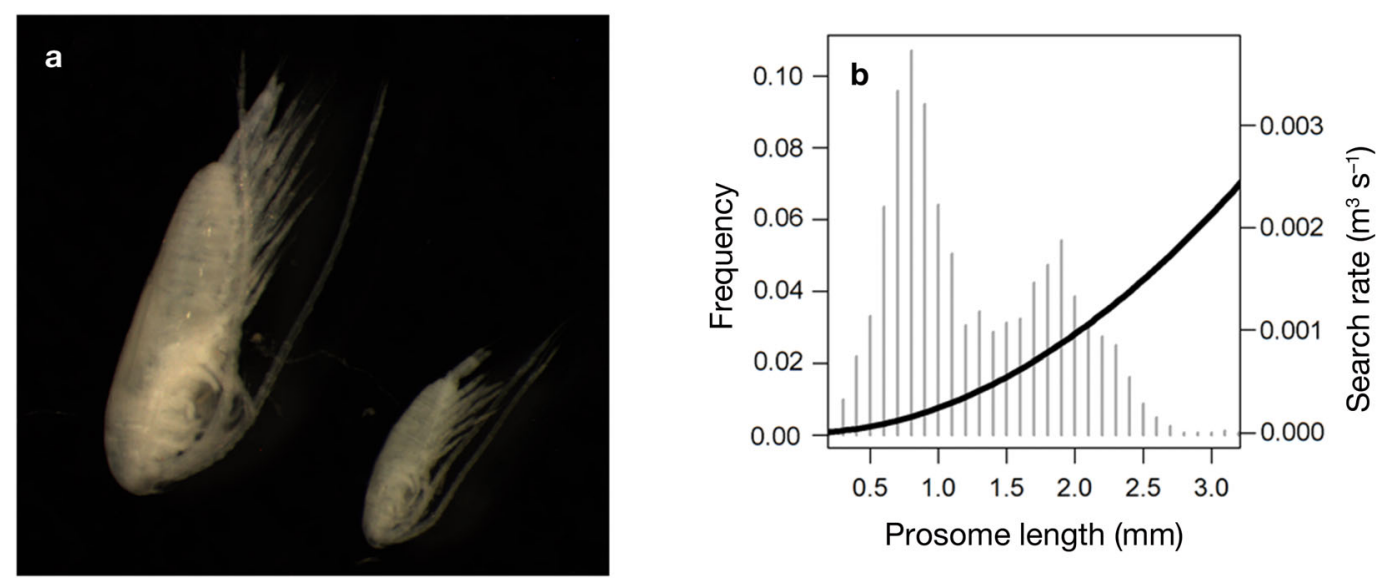

Fig. 1. Copepods of various sizes as prey for sandeel Ammodytes marinus. (a) Photo of typical copepods found in sandeel stomachs in the North Sea, representing the 2 size groups (prosome lengths of $2 \mathrm{~mm}$ and $1 \mathrm{~mm}$ ) applied in the present model. (b) Search rate as a function of prey size for a fixed prey biomass concentration (black curve; generated using Eq. 8 in Table 1 and a biomass concentration of $0.06 \mathrm{~g} \mathrm{~m}^{-3}$ ) superimposed on top of the size distribution of copepods found

(van Deurs et al. 2013) in the layer of copepods in mid water on the slopes of Dogger Bank (Jónasdóttir \& Koski 2011). Model parameters were found in the literature: energy density of copepods (Corner \& O'Hara 1986), length-weight conversions (Uye 1982, van Deurs et al. 2013), sandeel physiology (van Deurs et al. 2011), North Sea water temperatures (taken from van Deurs et al. 2010), seasonal and diurnal cycles in surface irradiance as a function of latitude, and optical capacity of the fish eye (Aksnes \& Utne 1997). Further details about model parameters are summarized in Table 1.

Energy intake was predicted for different sizes of sandeel, ranging from newly metamorphosed sandeels of $5 \mathrm{~cm}$ (Wright \& Bailey 1996) all the way to $17 \mathrm{~cm}$, which is the maximum attainable length of lesser sandeels in the central North Sea (Boulcott \& Wright 2008, Jensen et al. 2011). Our analysis focused on 2 distinct size groups of copepods, viz. prosome lengths of 1 and $2 \mathrm{~mm}$ (Fig. 1a). These 2 size groups roughly represent the 2 peaks of the bimodal size distribution of copepods found in stomachs of sandeels from the Dogger area (Fig. 1b).

\section{RESULTS}

\section{Prey concentration}

For the entire range of sandeel lengths (5 to $17 \mathrm{~cm}$ ) and prey biomass concentrations (0.001 to $0.1 \mathrm{~g} \mathrm{ww}$ $\mathrm{m}^{-3}$ ) considered, the predicted net energy uptake 

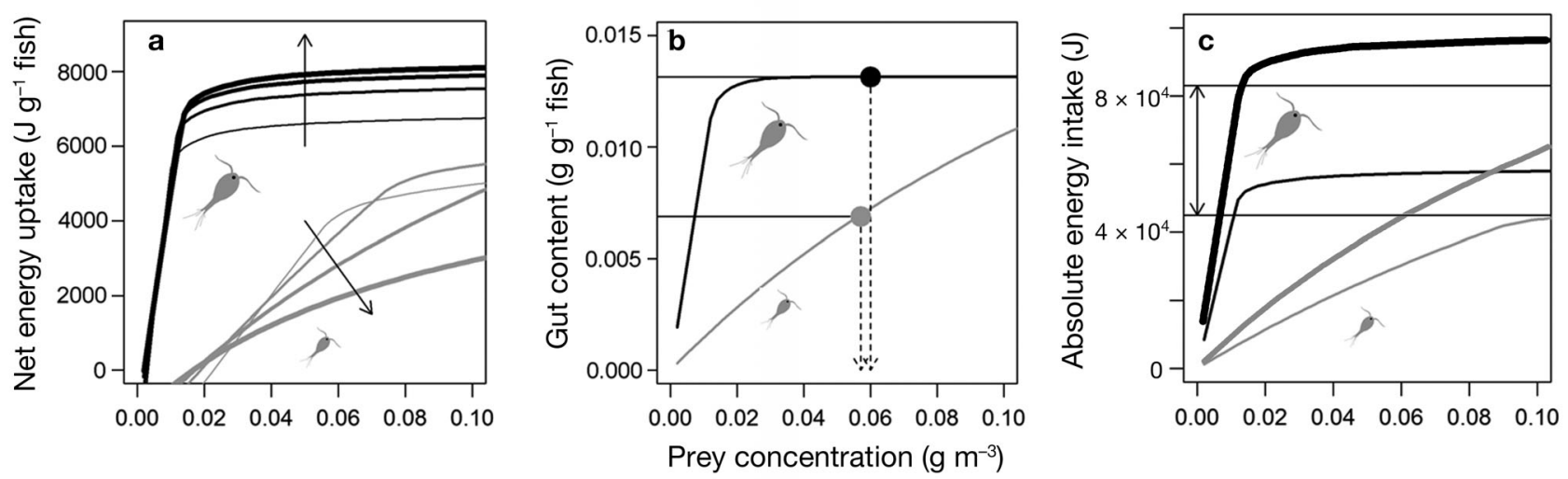

Fig. 2. (a) Specific net energy consumption of sandeel Ammodytes marinus as a function of prey concentration for large (2 mm; black lines) and small copepods ( $1 \mathrm{~mm}$; grey lines). Line thickness represents fish length (5, 9, 13, $17 \mathrm{~cm})$. Increasing fish size results in higher specific energy uptake (vertical arrow) due to increasing relaxation of search rate limitation for larger prey. For smaller prey, specific energy uptake decreases (diagonal arrow) with fish size due to increasing handling time limitation. (b) Average specific gut content (fish length $=12 \mathrm{~cm}$ ) as a function of prey concentration for large (black) and small copepods (grey). Dots correspond to the average specific gut contents observed for sandeels in spring in the study area (van Deurs et al. 2014). The default prey concentration was $0.06 \mathrm{~g} \mathrm{~m}^{-3}$. (c) Absolute energy intake (consumed energy integrated over the feeding season) as a function of prey concentration for large (black) and small copepods (grey) and 2 size groups of fish (11 and $13 \mathrm{~cm}$, represented by line thickness). Horizontal lines indicate the range of corresponding values found for sandeels in the study area (van Deurs et al. 2013), where the size distribution of the ingested copepods is shown in Fig. 1b

( $\mathrm{J} \mathrm{g}^{-1}$ fish) was considerably higher for large copepods (prosome length $=2 \mathrm{~mm}$ ) compared to smaller copepods (prosome length $=1 \mathrm{~mm}$; Fig. 2a). However, the difference in net energy uptake between diets consisting of small or large copepods was most pronounced when prey biomass concentration was low and for large fish sizes. Concentrations of small prey below $0.02 \mathrm{~g} \mathrm{~m}^{-3}$ resulted in negative net energy uptake (i.e. causing starvation and reserve depletion). For large copepods, net energy uptake reached a ceiling at prey concentrations around 0.02 $\mathrm{g} \mathrm{m}^{-3}$, above which any further increase in concentration did not considerably affect net energy uptake. For the small copepods, net energy uptake leveled off at $0.06 \mathrm{~g} \mathrm{ww} \mathrm{m}^{-3}$ in small fish, but never reached a ceiling for the largest fish. In general, small fish did relatively better on small copepods compared to large fish, as they were less limited by the handling time and to a larger extent limited by stomach capacity. However, the opposite was the case for large copepods, where the small fish attained lower energy intake rates than large fish. This was mainly due to search rate limitations in small fish (i.e. low swimming velocity and small reaction radius). Comparison of predicted gut content (Eq. 5 in Table 1) and absolute energy uptake (Eq. 2 integrated over the foraging season) to the corresponding values derived from sandeel stomachs collected in the Dogger area (van Deurs et al. 2013, 2014) indicated that a prey concentration of $0.06 \mathrm{~g} \mathrm{~m}^{-3}$ is within the range that can be observed in the North Sea Dogger area in spring (Fig. 2b,c).

\section{Handling time limitation}

Sandeels were sensitive to handling time when feeding on small copepods but not when feeding on large copepods (Fig. 3a). For a diet of large copepods, net energy uptake was independent of handling time, indicating that consumption was not handling time limited at these prey densities, but constrained by search time and encounter rate. However, for small copepods, the effect of handling time limitation increased with increasing fish size. For the large fish, net energy uptake was halved at the default handling time $(H=2 \mathrm{~s})$ compared the assumption of no handling time $(H=0 \mathrm{~s})$. Even when handling time was taken out of the model $(H=0 \mathrm{~s})$, net energy uptake was roughly $50 \%$ higher with large copepods compared to small copepods.

\section{Energy density of the prey}

While copepod size influences detection distance and encounter rate, the energy density affects the profitability of each encounter, and both strongly 

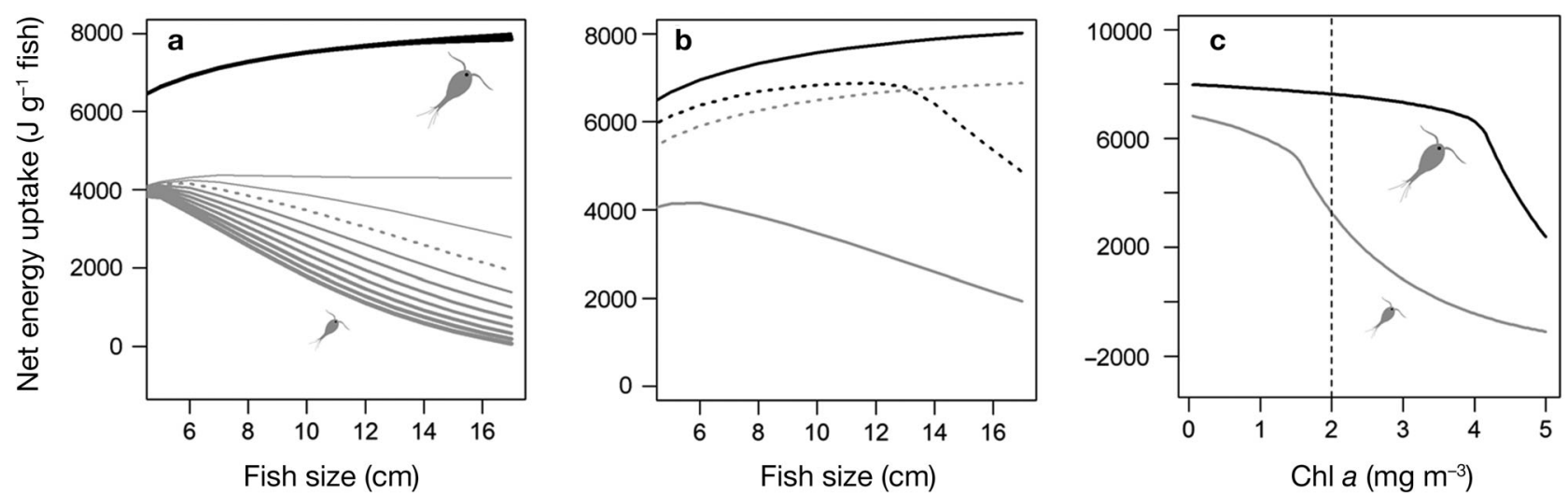

Fig. 3. (a) Sensitivity of the copepod size-energy uptake relationship to the choice of handling time (range: 0 to $9 \mathrm{~s}$, represented by increasing line width, with the upper grey line representing $0 \mathrm{~s}$ and the line furthest down being $9 \mathrm{~s}$ ) for large (black lines) and small copepods (grey lines). Dashed line represents the default handling time ( $H, 2 \mathrm{~s})$. Individual black lines cannot be distinguished, because changing handling time does not affect net energy uptake when the diet is composed of large copepods. (b) Comparing 4 different combinations of prey size and energy density. Black solid line represents a default simulation for large copepods $\left(5600 \mathrm{~J} \mathrm{~g}^{-1}\right)$, and the black dashed line represents an explorative simulation for large copepods with a low energy density $\left(3200 \mathrm{~J} \mathrm{~g}^{-1}\right)$. Grey solid line represents a default simulation for small copepods $\left(3200 \mathrm{~J} \mathrm{~g}^{-1}\right)$, and the dashed grey line signifies small copepods with a hypothetical high energy density (5600 J g ${ }^{-1}$ ). Both larger size and higher energy density of large copepods contribute to energy uptake across all fish sizes. (c) Effect of chl a concentration on net energy uptake of a $12 \mathrm{~cm}$ sandeel Ammodytes marinus feeding on large (black line) or small copepods (grey line). Vertical dashed line represents the default chl a level applied

influence net energy uptake rate. By comparing a baseline with large copepods to a situation with large copepods and low energy density $\left(\partial=3200 \mathrm{~J} \mathrm{~g}^{-1}\right)$ and one for small copepods and a high energy density $\left(\partial=5600 \mathrm{~J} \mathrm{~g}^{-1}\right)$ we isolated the effect of energy density from that of prey size (Fig. 3b). For a diet of large copepods, the importance of energy density is relatively small for fish $<13 \mathrm{~cm}$. This is because a slower digestion rate (Eq. 6 in Table 1) counteracts the nutritional benefits of energy-rich prey. In contrast, fish $>13 \mathrm{~cm}$ benefit from higher energy density in their prey because these fish are rarely limited by stomach or digestion capacity as they have a higher maximum gut capacity $\left(S_{\max }\right)$.

\section{Chl $a$ and optical properties of the water}

Search rate (Eq. 8 in Table 1) increases exponentially with copepod size, at least doubling the clearance volume when going from $1 \mathrm{~mm}$ to $2 \mathrm{~mm}$ copepods (Fig. 1b). This is mainly because the predator can detect prey at a longer distance when the prey constitutes a larger visual object. In our basic environment, sandeels change from being digestion limited to encounter limited at a chl a concentration of $1.5 \mathrm{mg} \mathrm{m}^{-3}$ for small copepods, whereas feeding rates on large copepods is only significantly reduced when chl a concentration exceeds $4 \mathrm{mg} \mathrm{m}^{-3}$ (Fig. 3c). When encounter rate becomes limiting due to turbidity, the drop in prey detection distance (Eq. 9 in Table 1) and energy intake with turbidity is steeper for large prey.

\section{DISCUSSION}

Our results illustrate how going from a situation where large Calanus copepods dominate the prey field to a situation where smaller copepods dominate may reduce the food consumption of large sandeels more than that of small sandeels, with implications for the specific growth potential.

We have related copepod size to the growth potential of zooplanktivorous fish. We used a mechanistic model to predict surplus energy uptake integrated over the feeding season. The model was explicitly parameterized for lesser sandeels in the central North Sea (Dogger) feeding on 2 distinct size groups of calanoid copepods: one group of small species with an average prosome length of $1 \mathrm{~mm}$ and the relatively larger Calanus sp. represented by a prosome length of $2 \mathrm{~mm}$. Model predictions were in general comparable to field observations, which were used to guide the analysis into the relevant range of prey concentrations. It is in particular noteworthy how the observed difference in gut content between fish feeding on small copepods vs. large copepods matches the predicted difference at a simulated prey 
concentration $\left(0.06 \mathrm{~g} \mathrm{ww} \mathrm{m}^{-3} \sim 84\right.$ large copepods $\mathrm{m}^{-3}$ ) characteristic for the Dogger area (i.e. 50 to 100 Calanus $\mathrm{m}^{-3}$ at ca. $30 \mathrm{~m}$ depth on the western slopes of Dogger Bank; Jónasdóttir \& Koski 2011). Our main finding is that when large Calanus are replaced by smaller copepod species, the potential growth rate of sandeels is roughly halved, even when the copepod biomass concentration is kept constant.

The level of detail in the model and the speciesspecific parameterization further allowed us to identify the key underlying processes responsible for this marked difference driven by food quality. Visual constraint was the most important factor, but handling time limitation and energy content were also important and provided stronger constraints with increasing fish length. Consequently, in situations where small copepods dominate the prey field, the model predicts that small-sized sandeels can achieve higher specific growth rates than their larger counterparts, whereas the opposite is the case when large copepods dominate.

Visual capacity and light-related constraints on predator-prey interactions are well known (i.e. Aksnes \& Utne 1997, Varpe \& Fiksen 2010). The present study sheds new light on the interactions between prey size and detection distance, illustrated by 2 distinct size groups of copepods dominating the North Sea system and the diet of sandeels (Pitois et al. 2009, van Deurs et al. 2013). At typical chl a concentrations of $2 \mathrm{mg} \mathrm{m}^{-3}$, visual capacity explained nearly half of the negative effect of a diet shift from large copepods to small copepods. However, the magnitude of the negative effect was strongly influenced by the chl a concentration, with a relatively small negative effect in clear water where small copepods could be detected far enough away to cancel out the role of visual capacity. However, as increasing chl a concentrations caused increased scattering of light, the negative effect of small prey size increased rapidly. For certain intervals of chl a concentrations, small changes in the greening of the water can have major implications for energy uptake rates, whereas in other chl a intervals variation has almost no effect (tipping point effect). Copepods are known to be patchily distributed, occupy different layers of the water column, and perform vertical migrations (Daro 1988). For instance, in some areas of the North Sea, small copepods with limited reserves have been observed to mainly reside in the proximity of the chlorophyll maximum layer (Daro 1988, Koski et al. 2011), while Calanus finmarchicus migrate between different layers (Daro 1988) or reside deeper down in the water column (Jónasdóttir \&
Koski 2011). In the central North Sea, large copepods are advected in from surrounding deep oceans and become trapped in the shallow areas, with few opportunities to escape predation through vertical migration to deep water.

Energy density of the relatively long-lived overwintering Calanus is much larger than for smaller, short-lived, and non-overwintering copepods in the North Sea (Corner \& O'Hara 1986). In the present study, we found that higher energy density in large copepods explained roughly $10 \%$ of the higher energy uptake rates for small- and medium-sized sandeels. This is because the model assumes a negative correlation between digestion rate and energy content, which counteracted the positive effect of higher energy content. The largest sandeels benefitted relatively more from higher energy density in their prey, as the full stomach capacity was almost never reached in the model. This outcome of the model is in line with the field study reported by van Deurs et al. (2014), who concluded that the specific gut content $\left(\mathrm{g} \mathrm{g}^{-1}\right.$ fish) of large sandeels (mean length $15.14 \mathrm{~cm}$ ) was only $64 \%$ of what was found for smaller sandeels (mean length $10.65 \mathrm{~cm}$ ).

When feeding on small copepods, handling time constraints were a problem for the largest of the fish. Here even a short handling time of $2 \mathrm{~s}$ (our default choice) reduced energy uptake rates by roughly $50 \%$, compared to a hypothetical scenario with no handling time. In contrast, newly metamorphosed sandeels $(5 \mathrm{~cm})$ did not experience handling time limitations. With a diet of large copepods, handling time limitation was never a problem. According to the strict conceptual understanding of handling time limitation (Jeschke et al. 2002), only predators that digest prey items faster than they are handled are likely to be limited by handling time. From the evacuation rate and handling times applied here it follows that sandeels digest small copepods faster than the maximum achievable consumption rate (ad libitum prey availability) during some time intervals of the foraging period. This was not the case for large copepods. In all comparative simulations, it was assumed that a difference in handling time between the 2 size groups of copepods was negligible. We do not have data or know of studies that can help assess whether this assumption is valid, but as seen in Fig. 3a, even if handling time of larger copepods is considerably higher than $2 \mathrm{~s}$ (our default value), handling time limitation will not constrain energy uptake rates for a diet dominated by large copepods.

In general, our results indicated that going from a situation where large Calanus copepods dominate 
the prey field to a situation where smaller copepods dominate should affect the food consumption of large sandeels more than that of small sandeels. This means that as the fish grow, it will be increasingly more difficult to maintain a high growth rate, unless the fish actively migrate toward more productive feeding grounds or invest more time in foraging. As the distribution of $C$. finmarchicus changed during the late 1980s, herring populations responded by migrating farther (Corten 2000). However, sandeels are behaviorally attached to a specific type of sandy bottom habitat, and are therefore not free to migrate. Increasing foraging activity means spending more time away from their refuge within the substrate, which will most likely result in increased predation risk. Consequently, shifting to a regime dominated by small copepods would either elevate natural mortality or reduce growth, and in turn would also lead to a reduction in reproductive effort.

According to an analysis of a continuous plankton recorder (CPR) time series, the zooplankton community changed abruptly in the late 1980s (Beaugrand et al. 2003, Beaugrand 2004). However, an earlier CPR time-series analysis (Planque \& Fromentin 1996) showed a more gradual decline in C. finmarchicus after the mid-1980s rather than the abrupt change suggested by Beaugrand (2004). The more gradual decline suggested by Planque \& Fromentin (1996) matches a gradual change from increasing length-atage prior to 1987 to declining length-at-age in the period thereafter off the Scottish coast (Wanless et al. 2005, Frederiksen et al. 2011, van Deurs et al. 2014). Furthermore, in the early 2000s, sandeel recruitment and spawning stock biomass in the North Sea suddenly declined (ICES 2013).

The results presented here have consequences for how we understand copepod-fish interactions and zooplankton composition as an important facilitator of mid-trophic energy transfer. The study suggests that changes in prey quality induced by climate change or other factors can have major implications for growth, survival, and reproduction of zooplanktivorous fish. In particular, the results indicated that a shift from large energy-rich Calanus copepods to smaller non-diapausing copepod species will impact the specific growth potential of sandeels.

To date, no evidence of filter-feeding in sandeels has been presented. However, a number of zooplanktivorous species occupying the same niche in the food web as the sandeel are known for their ability to shift between particulate feeding and filterfeeding, making them more adaptable to low visibility (Checkley et al. 2009). Perhaps filter-feeding is also an advantageous strategy when small copepods dominate the prey field. Hence, further elaboration of the broader ecological consequences of qualitative changes in the zooplankton community could be made by extending the present model with a filterfeeding component.

Acknowledgements. M.v.D. acknowledges funding from the Danish Council for Independent Research (DFF-400200114), Nordic Marine Academy and the European Fisheries Foundation. C.J. acknowledges funding from the Research Council of Norway.

\section{LITERATURE CITED}

Aksnes DL, Utne ACW (1997) A revised model of visual range in fish. Sarsia 82:137-147

Andersen NG (1999) The effects of predator size, temperature, and prey characteristics on gastric evacuation in whiting. J Fish Biol 54:287-301

Beaugrand G (2004) The North Sea regime shift: evidence, causes, mechanisms and consequences. Prog Oceanogr 60:245-262

> Beaugrand G, Brander KM, Lindley JA, Souissi S, Reid PC (2003) Plankton effect on cod recruitment in the North Sea. Nature 426:661-664

Boulcott P, Wright PJ (2008) Critical timing for reproductive allocation in a capital breeder: evidence from sandeels. Aquat Biol 3:31-40

Brooks JL, Dodson SI (1965) Predation, body size, and composition of plankton. Science 150:28-35

Checkley D, Alheit J, Oozeki Y, Roy C (2009) Climate change and small pelagics. Cambridge, Cambridge University Press,

Ciannelli L, Drodeur RD, Buckley TW (1998) Development and application of a bioenergetics model for juvenile walleye pollock. J Fish Biol 52:879-898

Corner EDS, O'Hara SCM (1986) The biological chemistry of marine copepods. Clarendon Press, Oxford

Corten A (2000) A possible adaptation of herring feeding migrations to a change in timing of the Calanus finmarchicus season in the eastern North Sea. ICES J Mar Sci 57:1261-1270

> Coyle KO, Eisner LB, Mueter FJ, Pinchuk AI and others (2011) Climate change in the southeastern Bering Sea: impacts on pollock stocks and implications for the oscillating control hypothesis. Fish Oceanogr 20:139-156

Daro MH (1988) Migratory and grazing behavior of copepods and vertical distribution of phytoplankton. Bull Mar Sci 43:710-729

Frederiksen M, Elston DA, Edwards M, Mann AD, Wanless S (2011) Mechanisms of long-term decline in size of lesser sandeels in the North Sea explored using a growth and phenology model. Mar Ecol Prog Ser 432:137-147

Hampe A, Petit RJ (2005) Conserving biodiversity under climate change: the rear edge matters. Ecol Lett 8:461-467

> Helaouët P, Beaugrand G (2009) Physiology, ecological niches and species distribution. Ecosystems 12:1235-1245

Huse G, Fiksen Ø (2010) Modelling encounter rates and distribution of mobile predators and prey. Prog Oceanogr 84:93-104 
ICES (2013) Report of the Herring Assessment Working Group for the Area South of $62^{\circ}$ N. ICES CM 2013/ ACOM:06. International Council for the Exploration of the Sea, Copenhagen

> Jensen H, Rindorf A, Wright PJ, Mosegaard H (2011) Inferring the location and scale of mixing between habitat areas of lesser sandeel through information from the fishery. ICES J Mar Sci 68:43-51

> Jeschke JM, Kopp M, Tollrian R (2002) Predator functional responses: discriminating between handling and digesting prey. Ecol Monogr 72:95-112

> Jónasdóttir SH, Koski M (2011) Biological processes in the North Sea: comparison of Calanus helgolandicus and Calanus finmarchicus vertical distribution and production. J Plankton Res 33:85-103

Kjellerup S, Dünweber M, Swalethorp R, Nielsen TG, Møller EF, Markager S, Hansen BW (2012) Effects of a future warmer ocean on the coexisting copepods Calanus finmarchicus and C. glacialis in Disko Bay, western Greenland. Mar Ecol Prog Ser 447:87-108

Koski M, Jónasdóttir SH, Bagoien E (2011) Biological processes in the North Sea: vertical distribution and reproduction of neritic copepods in relation to environmental factors. J Plankton Res 33:63-84

Macer CT (1966) Sandeels (Ammodytidae) in the southwestern North Sea: their biology and fishery. Ministries of Agriculture, Fisheries and Food: Fishery Investigations Ser II, Vol 24, No. 6. Her Majesty's Stationery Office, London, p 1-55

MacLeod CD, Santos MBA, Reid RJ, Scott BE, Pierce GJ (2007) Linking sandeel consumption and the likelihood of starvation in harbour porpoises in the Scottish North Sea: Could climate change mean more starving porpoises? Biol Lett 3:185-188

Mobley CM (1994) Light and water. Radiative transfer in natural waters. Academic Press, San Diego, CA

> Möllmann C, Kornilovs G, Fetter M, Köster FW, Hinrichsen HH (2003) The marine copepod, Pseudocalanus elongatus, as a mediator between climate variability and fisheries in the Central Baltic Sea. Fish Oceanogr 12:360-368

> Nielsen TG, Løkkegaard B, Richardson K, Pedersen FB, Hansen L (1993) Structure of plankton communities in the Dogger Bank area (North Sea) during a stratified situation. Mar Ecol Prog Ser 95:115-131

Pitois SG, Shaw M, Fox CJ, Frid CLJ (2009) A new fine-mesh zooplankton time series from the Dove sampling station (North Sea). J Plankton Res 31:337-343

> Planque B, Batten SD (2000) Calanus finmarchicus in the North Atlantic: the year of Calanus in the context of interdecadal change. ICES J Mar Sci 57:1528-1535

> Planque B, Fromentin JM (1996) Calanus and environment in the eastern North Atlantic. 1. Spatial and temporal patterns of C. finmarchicus and C. helgolandicus. Mar Ecol Prog Ser 134:101-109

Planque B, Taylor AH (1998) Long-term changes in zooplankton and the climate of the North Atlantic. ICES J Mar Sci 55:644-654

Radach G, Pätsch J (1997) Climatological annual cycles of nutrients and chlorophyll in the North Sea. J Sea Res 38: 231-248

Editorial responsibility: Edward Durbin, Narragansett, Rhode Island, USA
Schnack-Schiel SB, Hagen W (1994) Life cycle strategies and seasonal variations in distribution and population structure of four dominant calanoid copepod species in the eastern Weddell Sea, Antarctica. J Plankton Res 16: 1543-1566

Temming A, Herrmann JP (2001) Gastric evacuation in horse mackerel. I. The effects of meal size, temperature and predator weight. J Fish Biol 58:1230-1245

Uye S (1982) Length-weight relationships of important zooplankton from the Inland Sea of Japan. J Oceanogr Soc Jpn 38:149-158

van der Lingen CD, Hutchings L, Field JG (2006) Comparative trophodynamics of anchovy Engraulis encrasicolus and sardine Sardinops sagax in the southern Benguela: Are species alternations between small pelagic fish trophodynamically mediated? Afr J Mar Sci 28:465-477

> van Deurs M, van Hal R, Tomczak MT, Jónasdóttir SH, Dolmer P (2009) Recruitment of lesser sandeel Ammodytes marinus in relation to density dependence and zooplankton composition. Mar Ecol Prog Ser 381:249-258

> van Deurs M, Christensen A, Frisk C, Mosegaard H (2010) Overwintering strategy of sandeel ecotypes from an energy/predation trade-off perspective. Mar Ecol Prog Ser 416:201-214

van Deurs M, Hartvig M, Steffensen JF (2011) Critical threshold size for overwintering sandeels (Ammodytes marinus). Mar Biol 158:2755-2764

van Deurs M, Christensen A, Rindorf A (2013) Patchy zooplankton grazing and high energy conversion efficiency: ecological implications of sandeel behavior and strategy. Mar Ecol Prog Ser 487:123-133

> van Deurs M, Koski M, Rindorf A (2014) Does copepod size determine food consumption of particulate feeding fish? ICES J Mar Sci 71:35-43

> Varpe $\varnothing$, Fiksen $\varnothing$ (2010) Seasonal plankton-fish interactions: light regime, prey phenology, and herring foraging. Ecology 91:311-318

Verkuil Y, Van der Have TM, Van der Winden J, Chernichko II (2003) Habitat use and diet selection of northward migrating waders in the Sivash (Ukraine): the use of brine shrimp Artemia salina in a variably saline lagoon complex. Ardea 91:71-83

Wanless S, Harris MP, Redman P, Speakman JR (2005) Low energy values of fish as a probable cause of a major seabird breeding failure in the North Sea. Mar Ecol Prog Ser 294:1-8

Winslade P (1974) Behavioral studies on lesser sandeel Ammodytes marinus (Raitt). 3. Effect of temperature on activity and environmental control of annual cycle of activity. J Fish Biol 6:587-599

Wright PJ, Bailey MC (1996) Timing of hatching in Ammodytes marinus from Shetland waters and its significance to early growth and survivorship. Mar Biol 126: 143-152

> Yamaguchi A, Ikeda T (2000) Vertical distribution, life cycle, and developmental characteristics of the mesopelagic calanoid copepod Gaidius variabilis (Aetideidae) in the Oyashio region, western North Pacific Ocean. Mar Biol 137:99-109

Submitted: July 11, 2014; Accepted: October 23, 2014 Proofs received from author(s): January 6, 2015 